\title{
Type I Diabetes-Associated Tolerogenic Properties of Interleukin-2
}

\author{
Aziz Alami Chentoufi, ${ }^{1}$ Simon Gaudreau, ${ }^{2}$ Alex Nguyen, ${ }^{3}$ Mahmoud Sabha, ${ }^{4}$ \\ Abdelaziz Amrani, ${ }^{2}$ and Geyhad ElGhazali ${ }^{1,5}$ \\ ${ }^{1}$ Department of Immunology, Faculty of Medicine, King Fahad Medical City, Riyadh 11 525, P.O. Box 59046, Saudi Arabia \\ ${ }^{2}$ Immunology Division, Department of Paediatric, Faculty of Medicine and Health Sciences, University of Sherbrooke, \\ Sherbrooke, QC, Canada J1H 5N4 \\ ${ }^{3}$ Faculty of Medicine, Touro University Nevada, Henderson, NV 89014, USA \\ ${ }^{4}$ Faculty of Medicine, St. George's University, Bay Shore, NY 11706, USA \\ ${ }^{5}$ Faculty of Medicine and Medical Sciences, University of Shendi, Sudan
}

Correspondence should be addressed to Aziz Alami Chentoufi, chentoufiaziz@hotmail.com

Received 15 January 2011; Accepted 8 March 2011

Academic Editor: V. Geenen

Copyright ( 2011 Aziz Alami Chentoufi et al. This is an open access article distributed under the Creative Commons Attribution License, which permits unrestricted use, distribution, and reproduction in any medium, provided the original work is properly cited.

Type 1 Diabetes (T1D) results from insulin-producing beta cells destruction by diabetogenic T lymphocytes in humans and nonobese diabetic (NOD) mice. The breakdown of tolerance has been associated with a defect in the number and the function of naturally occurring regulatory $\mathrm{T}$ cells (nTreg) that are the master player in peripheral tolerance. Gene knockout experiments in mouse models have shown a nonredundant activity of IL-2 related to its critical role in inducing nTreg and controlling peripheral $\mathrm{T}$ cell tolerance. Whereas strong evidence has suggested that IL-2 is critically required for nTreg-mediated T1D control, several fundamental questions remain to be addressed. In this paper, we highlight the recent findings and controversies regarding the tolerogenic properties of IL-2 mediated through nTreg. We further discuss a potential link between the immunomodulatory role of interleukin-2 and the pathogenesis of type 1 diabetes.

\section{Introduction}

The induction of tolerance is critical for the maintenance of immune homeostasis and the prevention of autoimmune diseases, including type 1 diabetes (T1D). Tregs are crucial for suppressing autoimmune responses and maintaining peripheral immunological tolerance [1]. Defects in the number and function of immunoregulatory $\mathrm{CD}^{+} \mathrm{T}$ cells (nTregs) play a critical role in the breakdown of immune tolerance in the experimental model of spontaneous autoimmune diabetes nonobese diabetic (NOD) mouse $[2,3]$ and in humans with genetic susceptibility to T1D. Tregs arise during the normal process of $\mathrm{T}$ cell maturation in the thymus, and their differentiation can be induced ( iTreg) in the periphery by conversion of naive $\mathrm{CD} 4^{+} \mathrm{CD} 25^{-}$Foxp $3^{-}$ Tregs into $\mathrm{CD} 4^{+} \mathrm{CD} 25^{+} \mathrm{Foxp} 3^{+}$Tregs $[4,5]$. The influence of $\mathrm{n}$ Tregs in maintaining $\mathrm{T}$ cell tolerance is strongly supported by the observations of the development of autoimmune syndromes in mice lacking nTregs and by the findings that defects in Foxp3 gene expression in humans and mice lead to autoimmune syndromes in early life $[6,7]$. In agreement with these observations, the prevention of other autoimmune diseases such as rheumatoid arthritis (RA), inflammatory bowel disease (IBD), and type 1 diabetes (T1D) has been achieved by reconstitution of autoimmuneprone mice with nTregs [8]. Emerging evidence has revealed the involvement of IL-2 as a major regulator of the survival and suppressive function of nTreg $[9,10]$. Work from Santamaria's group [11] has revealed that IL-2 production was reduced in NOD mice and correlated with impairment in nTreg function. Furthermore, treatment with IL-2 has been shown to induce Treg expansion and activation in humans and mice [9] and protection against diabetes in NOD mice [12]. In the last decade, much progress has been made in 
understanding the role of the IL-2/IL-2 receptor (IL-2R) axis in promoting $n$ Treg differentiation and its importance in the interface between tolerance and autoimmunity. This paper primarily focuses on our current understanding of the role of IL-2/nTreg in regulating autoimmune diabetes and its potential therapeutic application in patients with T1D. Recently, it has been shown that the administration of low doses of IL-2 at the onset of diabetes can induce a longlasting remission in NOD mice. Interestingly, IL-2 did not stimulate autoreactive effector $\mathrm{T}$ cells but rather specifically stimulated $\mathrm{CD}^{+}{ }^{+} \mathrm{Foxp}^{+}$Tregs in the pancreas, resulting in dampening the influence of the inflammatory environment [12]. Here, we further highlight the role of IL-2/IL-2R in autoimmune T1D, specifically through the modulation of nTregs development and function.

\section{Biological Importance of IL-2/IL-2R Signaling}

IL-2 is a $15 \mathrm{kDa} 4$-bundled $\alpha$-helical protein mainly produced by activated $\mathrm{CD}^{+} \mathrm{T}$ lymphocytes. However, the expression of IL- 2 by naïve $\mathrm{CD} 8^{+} \mathrm{T}$ cells, dendritic cells, and thymic cells has also been reported $[13,14]$. The magnitude and duration of the $\mathrm{T}$ cell immune response is dependent on the interaction of IL-2 with its high-affinity IL-2 receptor (IL-2R) which is composed of $\alpha, \beta$ and $\gamma$ subunits. The intermediate affinity IL-2R is composed of IL-2R $\beta$ (CD122) and IL-2R $\gamma$ (CD132) and is constitutively expressed on resting $\mathrm{T}$ lymphocytes. However, IL-2R $\alpha$ (CD25) is only induced after T-cell activation, which allows the formation of the high-affinity IL-2R [15]. The biological activities resulting from the binding of IL-2 to its receptor on Tcells have not yet been fully defined. Evidence has shown that in conventional $\mathrm{T}$ cells, the effects of occupation of the high affinity IL-2R are mediated by at least two major signaling pathways, the JAK-STAT and the PI3K pathways. The activation of the JAK-STAT pathway is initiated by the activation of the Janus Kinases (JAK) JAK1 and JAK3. JAK1 is primarily associated with the serine-rich region of the IL-2R, whereas JAK3 seems to be associated with both the proximal and distal regions of the cytoplasmic domain of the common $\gamma$-chain. The stimulation of JAK molecules initiates a cascade of activation involving the signal transducers and activators of transcription (STAT5a/b) factors as well as the phosphatidylinositol 3-kinse (PI3K) and ras-mitogenactivated protein kinase (MAPK) signaling pathways [15, 16]. The activation of these signaling molecules results in modulation of target gene expression involved in cell cycle progression (gene encoding cycling family proteins $\mathrm{A}, \mathrm{B}, \mathrm{C}$, D2, D3, and E), anti-apoptosis (Cmyc, C-fos, C-jun, Bcl2, and bclx), and in the suppression of cytokine (SOCS and CIS) signaling (Figure 1) [17, 18].

The JAK/STAT5 pathway is important for many cellular responses, including differentiation, proliferation, and oncogenesis. For example, STAT5 ${ }^{-/}$mice have a profound defect in mammary gland development and in prolactin response, whereas STAT5 $\mathrm{B}^{-/-}$mice display a defect in growth hormone response [19]. Simultaneous inactivation of STAT5A/B genes has revealed a requirement for both proteins in myeloid and lymphoid cell proliferation. Indeed, myeloid cells, mast cells, peripheral $\mathrm{T}$ cells, and $\mathrm{NK}$ and $\mathrm{B}$ cells display impaired proliferation and/or survival in STAT5 ${ }^{-1-}$ mice [20-22]. STAT5 has also been shown to be involved in maintaining $\mathrm{CD} 4{ }^{+} \mathrm{CD} 25^{+}$regulatory $\mathrm{T}$ cell homeostasis and self-tolerance [23], Th2 differentiation, and $\mathrm{CD}^{+} \mathrm{T}$ cell homeostasis [24]. $\mathrm{STAT5}^{-/-}$mice have a decreased number of $\mathrm{CD} 8^{+}$ T cells, whereas STAT5 transgenic mice have an increased number of these cells, which correlates with anti-apoptotic protein $\mathrm{Bcl}-\mathrm{x}_{\mathrm{L}}$ expression [25]. Ectopic expression of $\mathrm{Bcl}-$ $\mathrm{x}$ rescues $\mathrm{STAT5}^{-/-} \mathrm{BM}$ cells from apoptosis indicating that STAT5 promotes survival of myeloid progenitor cells through the ability to induce the transcription of the Bcl$\mathrm{x}$ gene [26]. Finally, STAT5 ${ }^{-1-}$ mice exhibit autoimmune pathology in a manner very similar to IL-2-deficient mice. This disease correlates with decreased numbers of nTregs, which undergo apoptosis at increased rates in the absence of STAT5 [26]. Recently, it has been reported that a patient, with a missense mutation in the STAT5B gene, had no detectable expression of STAT5B and had decreased numbers and impaired function of nTregs [27]. Similarly, JAK3-/mice have low frequency of nTregs, increased amount of autoreactive $\mathrm{T}$ cells, and develop autoimmunity as is the case for IL-2-deficient and IL-2R-deficient mice [23]. These reports underlie the importance of IL-2/IL-2R signaling in the maintenance of immune tolerance.

\section{Naturally Occurring $\mathrm{CD4}^{+} \mathrm{CD25}^{+}$ Tregs and Autoimmunity}

Naturally occurring $\mathrm{CD} 4{ }^{+} \mathrm{CD} 25^{+}$regulatory $\mathrm{T}$ cells represent $5 \%-10 \%$ of the $\mathrm{CD} 4^{+} \mathrm{T}$ cell subset that critically contributes to maintenance of peripheral immune tolerance. These cells arise in the thymus and, after migrating to the periphery, exert their immunoregulatory functions. They are potent suppressor of organ-specific autoimmune diseases such as T1D, inflammatory bowel disease and gastritis, and they control allograft rejection and immunity to infectious agents such as parasites and viruses [28-30]. In mice, a day-3 neonatal thymectomy ( $\mathrm{d} 3 \mathrm{Tx}$ ) leads to the development of multiorgan autoimmune disease [31]. Subsequently, the depletion of $\mathrm{CD} 4{ }^{+} \mathrm{CD} 25^{+}$Tregs leads to spontaneous development of various autoimmune diseases in genetically susceptible animals as well. The adoptive transfer of $\mathrm{CD} 4^{+} \mathrm{CD} 25^{+}$nTreg prevents the development of such organ-specific autoimmunity [32]. In the T1D NOD mouse model, it has been shown that the pool of $\mathrm{CD}^{+}{ }^{+} \mathrm{CD} 25^{+}$regulatory $\mathrm{T}$ cells decreases with the progression of diabetes $[33,34]$ and that administration of these cells affords protection against the development of diabetes $[35,36]$. In the mouse, nTreg are considered as resting antigen-experienced cells and display heterogeneous combination of cell surface markers associated with naive and activated $\mathrm{T}$ cells. nTregs constitutively express highaffinity IL-2R $\alpha$ (CD25) and Foxp3, a forkhead winged helix transcriptional regulator that controls their development and functions [37]. The mutation of Foxp3 resulted in drastic loss of nTregs and fatal lymphoproliferative process that leads to multiorgan-autoimmune diseases of nTregs in mice and humans. The transfer of nTreg cells from wild-type mice 


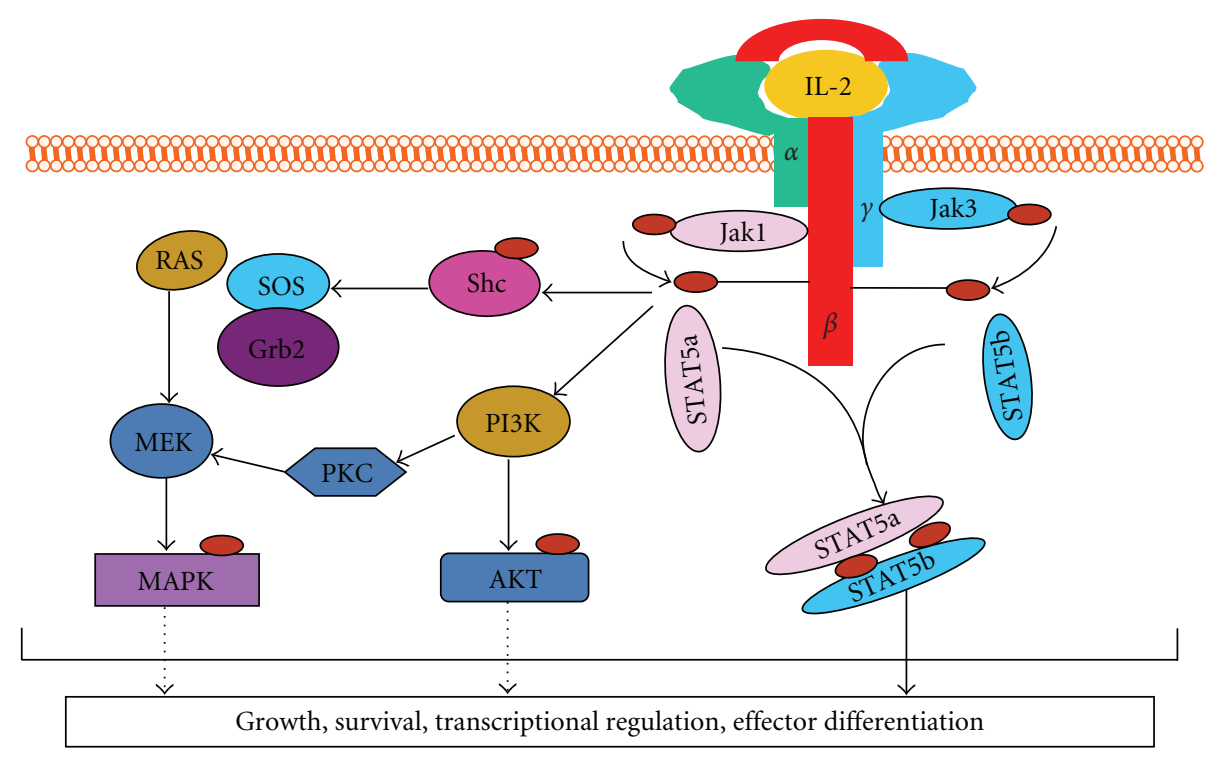

FIGURE 1: IL-2 receptor signaling. The binding of IL-2 to IL-2R leads to the initiation of signal transduction. Janus-activated kinase 3 (JAK3) molecules that are associated with the $\gamma \mathrm{c}$, and JAK1 molecules that are associated with IL-2R $\beta$, phosphorylate $(\bigcirc)$ tyrosine residues in the cytoplasmic tail of IL-2R $\beta$, the $\gamma \mathrm{c}$ and the JAK molecules themselves. The JAKs activation induced a cascade of activation of signal transducer and activator of transcription (STAT5a/b) factors, leading to their dimerization translocation to the nucleus, as well as phosphatidylinositol 3-kinse (PI3K) and ras-mitogen-activated protein kinase (MAPK) signaling pathways. These signaling molecules activation results in, modulation of target genes expression involved in cell cycles progression, antiapoptosis, and in the suppression of cytokine signaling.

to scurfy mice rescues the animals from the fatal disease $[7,38]$. Other cell surface markers have been shown to be expressed by nTregs, including high levels of CD5, CD62L, and CD69. Beside the expression of high-affinity IL-2R $\alpha$ (CD25), at resting state, nTreg constitutively express high levels of other feature markers such as the glucocorticoidinduced TNFR (GITR) family of related proteins [39], OX40 (CD134) [40,41], and CTLA-4 [42, 43] that also contribute to their suppressive function. Importantly, mice deficient in Foxp3 gene (scurfy mice) rapidly develop a fatal lymphoproliferative disease similar to that seen in mice lacking CTLA- 4 or TGF- $\beta$ [44]. Recently, it has been shown that OX40 is a key factor in shaping nTregs sensitivty to IL-2 and promoting their proliferation and survival toward accurate immune regulation [45].

We have previously reported that tolerogenic DCs are critical in maintaining nTregs pool in NOD mice. Using adoptive transfer experiments, we have shown that depletion of tolerogenic DCs before transferring splenocytes from diabetes-free NOD mice restored their diabetogenic potential, thereby underlying the importance of tolerogenic DC in nTregs maintenance [46]. Naïve $\mathrm{CD} 4^{+} \mathrm{CD} 25^{-} \mathrm{T}$ cells can be also converted into regulatory-like $\mathrm{T}$ cells after transduction with a retroviral vector coding for the FoxP3 gene. The transfer of these converted Tregs has been shown to prevent the development of autoimmune IBD [5, 38, 47]. Collectively, these data clearly indicate that Foxp3 plays a critical role for both development and function of nTreg in mice.

\section{Cytokines Profile and Cytokines Receptor Signaling in nTreg}

The mechanisms by which IL-2 or other cytokines exert their effects via the cytokine receptors on nTreg have not been fully investigated yet. In conventional T cells, the effects of IL-2 are mediated by at least two major signaling pathways, the JAK-STAT and PI3K pathways. Several different studies have examined the role of JAK-STAT molecules in $\mathrm{CD} 4^{+} \mathrm{CD} 25^{+}$ nTreg development and function. The importance of JAK3 in IL-2 signaling has been further substantiated by the recent findings that homozygous point mutations or deletions of the Jak3 gene are found in autosomal recessive $\mathrm{T}-\mathrm{B}+$ severe combined immunodeficiency patients [48] as well as immunocompromised mice [49]. Indeed, mice deficient in JAK3 or STAT5A/B develop a severe immunodeficiency that is followed by multiple organ autoimmune diseases, a decreased number or the absence of $\mathrm{CD} 4{ }^{+} \mathrm{CD} 25^{+}$nTreg in their peripheral lymphoid organs, and early death. However, these mice have normal numbers of Tregs in the thymus, suggesting the role of these molecules in regulatory $\mathrm{T}$ cell development and homeostasis $[23,26]$. Interestingly, the overexpression of STAT5b in transgenic mice leads to an increased number of $\mathrm{CD} 4{ }^{+} \mathrm{CD} 25^{+}$nTreg [50].

The role of JAK-STAT and PI3K signaling pathways in Treg proliferation and immunoregulatory function is not yet fully defined. Recently, Bensinger et al. [51] have shown that freshly isolated $\mathrm{CD} 4^{+} \mathrm{CD} 25^{+}$nTreg maintain an intact JAKSTAT signaling pathway, whereas signaling downstream PI3K 
(particularly activation of AKT and p70S6K) is negatively regulated as a result of increased expression of phosphatase and a tensin homolog deleted on chromosome 10 (PTEN). Conversely, we found that in vitro stimulated Treg displayed a normal PI3K pathway while inhibiting JAK-STAT pathways, which results from a downregulation of JAK-STAT molecules expression as opposed to kinase activity (Chentoufi et al. Unpublished data). The inhibition of the JAK-STAT pathway could result from the high expression of SOCS2 and CIS molecules observed 24-48 h following nTreg stimulation with anti-CD3 and IL-2. These results may explain the hypoproliferative activity of regulatory $\mathrm{T}$ cells even after activation through TCR in the presence of IL2. Moreover, IL-2 generates signaling pathways through a cytokine receptor that contains a $\gamma$-chain common to several other cytokine receptors including IL-4, IL-7, IL-9, IL-15, and IL-21. These observations add more complexity to the problem of deciphering the role of other cytokines on $\mathrm{CD} 4{ }^{+} \mathrm{CD} 25^{+}$nTreg.

Recently, it has been reported that IL-4 can substitute for IL-2 to induce $\mathrm{CD} 4{ }^{+} \mathrm{CD} 25^{+}$nTreg-mediated proliferation and suppression in vitro. However, nTreg obtained from IL4-/- mice display normal suppressive activity, suggesting profound differences between in vitro and in vivo effects [52]. It has also been shown that STAT1-deficient mice are highly susceptible to autoimmune diseases resulting from a reduced number as well as a functional impairment of $\mathrm{CD} 4^{+} \mathrm{CD} 25^{+}$ nTreg, suggesting a role of IFNs on regulatory $\mathrm{T}$ cells [53]. Naturally occurring $\mathrm{CD} 4^{+} \mathrm{CD} 25^{+} \mathrm{T}$ cells constitutively express mRNA coding for IL-10, IL-4, IL-17, IL-21, IFN- $\gamma$, TNF- $\alpha$, and TGF- $\beta$ but do not express mRNA coding for IL$2[43]$.

The biological roles of cytokines production and interaction with their receptors in nTreg development and function have not yet been clearly delineated. Recently, McHugh et al. [43] have shown, through gene expression profiling experiments, that JAK-STAT regulatory proteins such as members of the SOCS family of proteins (SOCS-1, SOCS-3, and CIS) are upregulated in stimulated $\mathrm{CD} 4^{+} \mathrm{CD} 25^{+}$nTreg as compared to conventional T cells [43]. The hypoproliferative activity of activated nTreg in vitro and the increased expression of SOCS molecules could suggest that these molecules play a role as an internal control mechanism for $\mathrm{CD} 4^{+} \mathrm{CD} 25^{+}$ nTreg activation and expansion. SOCS molecules function to inhibit the proliferative effects of cytokines such as IFN- $\gamma$, IL-4, and IL-2 and can antagonize JAK3 and STAT5 activities [18].

\section{Critical Balance of IL-2 for Naturally Occurring $\mathrm{CD4}^{+} \mathrm{CD}^{+} 5^{+}$ Treg-Mediated T1D Control}

IL-2 was originally defined as a growth factor that stimulated the differentiation and proliferation of T lymphocytes [54]. The critical role of IL-2 on the survival and suppressive function of nTreg cells has been well documented [55]. Consistent with this, IL-2 administration has been shown to expand and activate nTreg cells in humans and mice $[9,10]$. Thus, although IL-2 has pleiotropic functions, its major impact is to favor nTreg cell activity [56]. Surprisingly, in IL2 or IL-2R knockout mice, T cells develop, and these mice acquire a lymphoproliferative syndrome and spontaneous autoimmune disease [57]. From these studies, two important roles for IL-2 in immune tolerance can be ascribed. First, the data showed that IL-2 played a critical role in programming $\mathrm{T}$ cells for activation-induced cell death (AICD). Second, increased evidence showed that IL-2 played an additional role in immune regulation aside from AICD. For instance, several groups have reported that in IL-2 and IL-2R knockout mice, the lymphoproliferative syndrome could be prevented by rIL-2 injection and bone marrow transplantation from wild-type mice [58].

Of importance, it was observed that IL-2 had to be provided at very early stages. For instance, delivery of IL2 a few days after birth resulted in low efficiency of disease improvement, suggesting that it was not the lack of IL-2 during later $\mathrm{T}$ cell activation in the periphery that was at fault in these mice. The dependence of nTreg cells on IL-2 was first suggested by transfer experiments performed by Klebb et al. These authors transferred spleen cells or thymocytes from IL2-/- mice treated with rIL-2 for 25-35 days into untreated 6-8-day-old IL-2-/- BALB/C mice. The IL-2 defect on the $\mathrm{BALB} / \mathrm{C}$ background is particularly severe and leads to death within 3 weeks. Depending on the number of transferred cells and the organ from which they were derived, some of the recipients lived for 7-10 months. Since no more IL-2 was available during that time, the authors suggested that "IL-2 induces a postnatal differentiation/maturation of regulatory cells necessary for self and non-self-discrimination". Kramer et al. have shown that IL-2-/- and IL-2R-/- bone marrow transfer into RAG-/- mice leads to the development of IL-2 deficiency syndrome, and early death of RAG-/- recipient mice [59].

Again, the disease could be prevented by the complementation with bone marrow from IL-2-sufficient mice. Transfer of $\mathrm{CD} 4{ }^{+} \mathrm{CD} 25^{+}$nTreg from wild-type mice induced the development of a lymphoproliferative syndrome in IL$2 \mathrm{R} \alpha-/-$ mice [60]. The most striking observation in IL$2-/-$ mice models is the lack of $\mathrm{CD} 4^{+} \mathrm{CD} 25^{+}$nTreg, suggesting a critical role for IL-2/IL-2R signaling in the generation and homeostasis of these cells. Indeed, mice deficient in IL-2, IL-2R [61], JAK-3 [23], or STAT5A/B [26] have an absent or reduced number of thymic and peripheral $\mathrm{CD}^{+} \mathrm{CD}^{+} 5^{+}$nTreg and consequently develop multiple organ autoimmune diseases. To evaluate the role of IL-2 expression on thymic nTreg development, Malek et al. rescued IL-2R $\beta$ knockout mice with an IL-2R $\beta$ transgene that was predominantly expressed in the thymus with negligible expression in the periphery $[60,61]$. In marked contrast to IL-2R $\beta-/-$ mice, the IL-2R $\beta$ transgene restored the normal levels of $\mathrm{CD} 4{ }^{+} \mathrm{CD} 25^{+}$nTreg and prevented the onset of a fatal autoimmune disease, further reinforcing the notion that IL-2 plays a critical role in the thymic development of nTreg.

The molecular mechanism by which IL-2 exerts its effect on the nTreg cell precursors in the thymus is as of yet not completely understood. In addition, the origin of IL2 in the thymus does not seem to be from $\mathrm{CD} 4^{+} \mathrm{CD} 25^{+}$ nTreg themselves or hematopoietic cells, but probably derives 


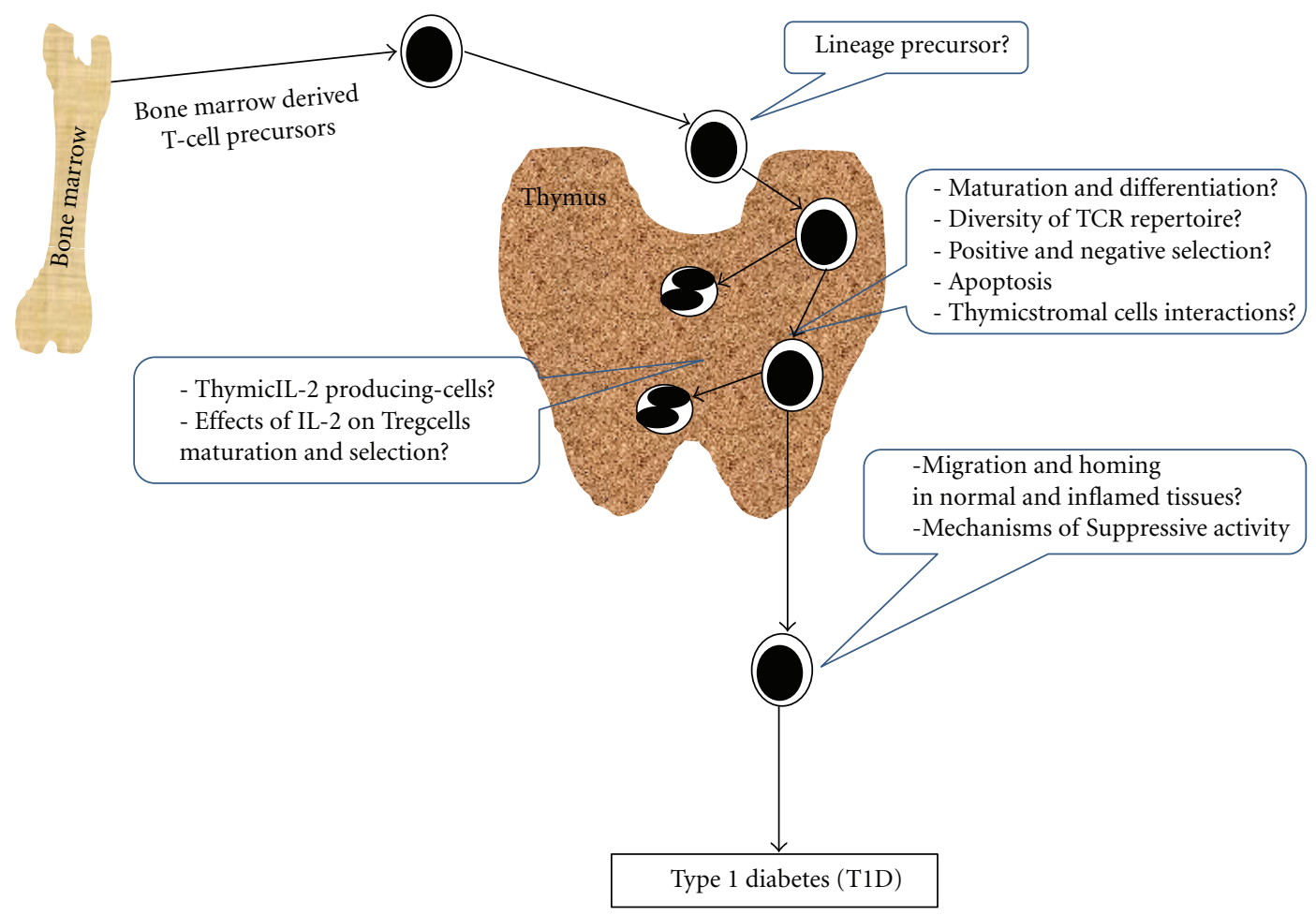

FIGURE 2: Fundamental questions about naturally occurring $\mathrm{CD} 4^{+} \mathrm{CD} 25^{+}$regulatory $\mathrm{T}$ cells development and function.

from radio-resistant thymic stromal cells. Indeed, chimeric bone marrow from IL-2-/ - and IL-2R $\alpha-/-$ mice develops functional $\mathrm{CD} 4{ }^{+} \mathrm{CD} 25^{+}$nTreg. Furthermore, lethally irradiated RAG2-/- mice that have been reconstituted with IL-2-/- bone morrow develop normal $\mathrm{CD} 4{ }^{+} \mathrm{CD} 25^{+}$nTreg [62]. The IL- 2 signaling requirement for peripheral expansion/homeostasis of $\mathrm{CD} 4^{+} \mathrm{CD} 25^{+} \mathrm{nTreg}$ has been shown by Malek et al. when $\mathrm{CD} 4^{+} \mathrm{CD} 25^{+}$nTreg from wild-type mice were adoptively transferred to IL-2R deficient mice (which normally produce IL-2). The recipient mice did not develop autoimmune diseases. In contrast, the adoptive transfer of $\mathrm{CD} 4^{+} \mathrm{CD} 25^{+}$nTreg from wild-type mice failed to confer the same benefits in IL-2-/- mice [61].

The requirement of IL-2 for nTreg suppression activity is still very controversial. When nTreg are adoptively transferred, they lose CD25 expression and hence are no longer responsive to IL-2. Nevertheless, these cells retain their suppressive activity in vitro [63]. However, the addition of IL-2 to nTreg eliminates this suppressive activity in vitro [64]. Conversely, $\mathrm{CD} 4^{+} \mathrm{CD} 25^{+}$nTreg from wild-type mice transferred to IL-2-deficient mice fail to prevent autoimmunity and in vitro suppression activity is completely abrogated by selective blocking of the IL- 2 receptor on nTreg during a coculture with responder $\mathrm{T}$ cells [65]. Furthermore, treatment of mice with anti-IL-2 or with CTLA-4 immunoglobulin to inhibit costimulatory signals also leads to a rapid decline in the number of $\mathrm{CD} 4^{+} \mathrm{CD} 25^{+}$ $\mathrm{T}$ cells [36].

Besides, NOD mice present a qualitative diminution of IL-2 production [11], and a genetic predisposing factor to
T1D development in humans and NOD mice is linked to IL-2/IL-2R gene polymorphisms [66]. It has been recently reported that insufficient IL-2 amounts in the pancreas are responsible for poor $n$ Treg cell survival in this tissue, which could lead to progressive breakdown of self-tolerance and the development of diabetes in NOD mice [67]. It has been recently shown that young prediabetic NOD mice treated with low-dose IL-2 alone, or together with rapamycin, can be protected from the development of disease [67-69]. Recently, it has been shown that low-dose IL-2 administration at diabetes onset can induce long-lasting remission in the treated mice. Interestingly, IL-2 seems to specifically stimulate the $\mathrm{CD}^{+} \mathrm{CD} 25^{+}$Treg cells in the pancreas rather diabetogenic effector $\mathrm{T}$ cells [12]. The mechanisms by which IL-2 selectively stimulate Tregs and reverse the disease in NOD diabetic mice is not yet understood. One mechanism of action of low-dose IL-2 would be the limitation of IFN$\gamma$ production by the islet-infiltrating effector $\mathrm{T}$ cells. In addition, by expressing high levels of the high affinity IL-2R, Tregs have an advantage in competing for low levels of IL-2 against effector T-cells in the microenvironment.

A number of contradictory observations regarding the number and function of nTreg in diabetic individuals and in mice have been reported. Regulatory $\mathrm{T}$ cell numbers have been reported to be decreased or normal in T1D [70-79], and functional assays have similarly described low, slightly decreased, or normal regulatory activity [80-86]. Nevertheless, a consensus regarding a few key points is developing. (i) There is clear evidence for the existence of natural regulatory $\mathrm{T}$ cells in both pre-T1D and postdiagnosis 
T1D subjects and mice. (ii) Some of the induced Treg cells display similar antigen specificity for $\beta$-cell autoantigens of non-T1D subject's Tregs [82]. (iii) In vitro and in vivo expansion of nTreg cells have been successful both in mice and human, particularly aided by the use of rapamycin $[87,88]$.

\section{Conclusion and Perspectives}

It has now been strongly established that $\mathrm{T}$ cell-mediated dominant immunoregulation is essential for maintaining immunologic self-tolerance and controlling immune responses to non-self-antigens. Among the various kinds of Tregs (iTreg, $\operatorname{Tr} 1$, and Th3), naturally occurring $\mathrm{CD} 4^{+} \mathrm{CD} 25^{+}$ nTreg play a key role in peripheral self-tolerance. A proteomic approach might contribute better to the identification of novel molecules involved in IL-2R signaling pathways for further therapeutic methods and specific cell surface markers for better isolation and characterization purposes. In vivo, if IL-2 seems to play a critical role in the thymic development of nTreg, which cells produce IL-2 in the thymus, at which stage of T-cell development IL-2 exert its effects, and what is the importance of IL-2 for the nTreg precursor cells differentiation are critical questions that need to be investigated. A possible explanation is that some thymocytes are confined within special thymic microenvironments containing high doses of IL-2, which could, in principle, transform them into anergic Treg cells. Such an anergic state could be obtained in vitro following Th1 clones incubation with IL-2 for 24 to $48 \mathrm{~h}$. These cells are rendered unresponsive to subsequent restimulation with antigen [89] although they remain fully responsive to IL-2 in vitro as long as IL-2 is provided. However, when restimulated with appropriate antigen and APC, they do not secrete cytokines, including IL-2 [90]. With respect to T cell maturation and central tolerance, not much is known about nTreg cells thymic maturation/differentiation. Whereas it is thought that nTreg cell generation depends on self-antigen expression in the thymus [91], a recent report from the Mathis' group [92] has shown that nTreg does not necessarily require the thymic expression of agonistic self-antigen. These questions and more need to be further investigated. Certainly, the development of technical tools and animal models will be invaluable to shed light into naturally occurring Treg biology and to provide novel immunomodulatory approaches that target (i) the downregulation of the immune system to prevent/treat autoimmune disease and allograft rejection and (ii) the control of immunity to infectious agents such as parasites and viruses (Figure 2).

\section{Abbreviations}

T1D: Type 1 diabetes

nTreg: Naturally occurring regulatory T-cells

IL-2: Interleukin-2.

\section{Conflict of Interests}

The authors have declared no conflict of interests.

\section{References}

[1] S. Sakaguchi, "Naturally arising $\mathrm{CD} 4^{+}$regulatory $\mathrm{T}$ cells for immunologic self-tolerance and negative control of immune responses," Annual Review of Immunology, vol. 22, pp. 531$562,2004$.

[2] S. P. Berzins, E. S. Venanzi, C. Benoist, and D. Mathis, "T-cell compartments of prediabetic NOD mice," Diabetes, vol. 52, no. 2, pp. 327-334, 2003.

[3] S. You, M. Belghith, S. Cobbold et al., "Autoimmune diabetes onset results from qualitative rather than quantitative agedependent changes in pathogenic T-cells," Diabetes, vol. 54, no. 5, pp. 1415-1422, 2005.

[4] D. J. Campbell and S. F. Ziegler, "Opinion: FOXP3 modifies the phenotypic and functional properties of regulatory T cells," Nature Reviews Immunology, vol. 7, no. 4, pp. 305-310, 2007.

[5] S. Hori, T. Nomura, and S. Sakaguchi, "Control of regulatory T cell development by the transcription factor Foxp3," Science, vol. 299, no. 5609, pp. 1057-1061, 2003.

[6] C. L. Bennett, J. Christie, F. Ramsdell et al., "The immune dysregulation, polyendocrinopathy, enteropathy, X-linked syndrome (IPEX) is caused by mutations of FOXP3," Nature Genetics, vol. 27, no. 1, pp. 20-21, 2001.

[7] R. S. Wildin, F. Ramsdell, J. Peake et al., "X-linked neonatal diabetes mellitus, enteropathy and endocrinopathy syndrome is the human equivalent of mouse scurfy," Nature Genetics, vol. 27, no. 1, pp. 18-20, 2001.

[8] H. Liu and B. P. Leung, " $\mathrm{CD} 4{ }^{+} \mathrm{CD} 25^{+}$regulatory $\mathrm{T}$ cells in health and disease," Clinical and Experimental Pharmacology and Physiology, vol. 33, no. 5-6, pp. 519-524, 2006.

[9] M. Ahmadzadeh and S. A. Rosenberg, "IL-2 administration increases $\mathrm{CD}^{+} \mathrm{CD} 25^{\text {hi }}$ Foxp $3^{+}$regulatory $\mathrm{T}$ cells in cancer patients," Blood, vol. 107, no. 6, pp. 2409-2414, 2006.

[10] H. Zhang, K. S. Chua, M. Guimond et al., "Lymphopenia and interleukin-2 therapy alter homeostasis of $\mathrm{CD} 4^{+} \mathrm{CD} 25^{+}$ regulatory T cells," Nature Medicine, vol. 11, no. 11, pp. 12381243, 2005.

[11] J. Yamanouchi, D. Rainbow, P. Serra et al., "Interleukin-2 gene variation impairs regulatory $\mathrm{T}$ cell function and causes autoimmunity," Nature Genetics, vol. 39, no. 3, pp. 329-337, 2007.

[12] Y. Grinberg-Bleyer, A. Baeyens, S. You et al., "IL-2 reverses established type 1 diabetes in NOD mice by a local effect on pancreatic regulatory T cells," Journal of Experimental Medicine, vol. 207, no. 9, pp. 1871-1878, 2010.

[13] H. Bassiri and S. R. Carding, "A requirement for IL-2/IL-2 receptor signaling in intrathymic negative selection," Journal of Immunology, vol. 166, no. 10, pp. 5945-5954, 2001.

[14] F. Granucci, C. Vizzardelli, N. Pavelka et al., "Inducible IL-2 production by dendritic cells revealed by global gene expression analysis," Nature Immunology, vol. 2, no. 9, pp. 882-888, 2001.

[15] J. X. Lin and W. J. Leonard, "Signaling from the IL-2 receptor to the nucleus," Cytokine and Growth Factor Reviews, vol. 8, no. 4, pp. 313-332, 1997.

[16] K. Sugamura, H. Asao, M. Kondo et al., "The interleukin2 receptor $\gamma$ chain: its role in the multiple cytokine receptor complexes and T cell development in XSCID," Annual Review of Immunology, vol. 14, pp. 179-205, 1996.

[17] M. Kubo, T. Hanada, and A. Yoshimura, "Suppressors of cytokine signaling and immunity," Nature Immunology, vol. 4, no. 12, pp. 1169-1176, 2003. 
[18] K. Shuai and B. Liu, "Regulation of JAK-STAT signalling in the immune system," Nature Reviews Immunology, vol. 3, no. 11, pp. 900-911, 2003.

[19] K. Paukku and O. Silvennoinen, "STATs as critical mediators of signal transduction and transcription: lessons learned from STAT5," Cytokine and Growth Factor Reviews, vol. 15, no. 6, pp. 435-455, 2004.

[20] M. Kieslinger, I. Woldman, R. Moriggl et al., "Antiapoptotic activity of Stat5 required during terminal stages of myeloid differentiation," Genes and Development, vol. 14, no. 2, pp. 232-244, 2000.

[21] V. Sexl, R. Piekorz, R. Moriggl et al., "Stat5a/b contribute to interleukin 7-induced B-cell precursor expansion, but abl- and bcr/abl-induced transformation are independent of Stat5," Blood, vol. 96, no. 6, pp. 2277-2283, 2000.

[22] M. Socolovsky, H. S. Nam, M. D. Fleming, V. H. Haase, C. Brugnara, and H. F. Lodish, "Ineffective erythropoiesis in Stat5a5b mice due to decreased survival of early erythroblasts," Blood, vol. 98, no. 12, pp. 3261-3273, 2001.

[23] A. Antov, L. Yang, M. Vig, D. Baltimore, and L. Van Parijs, "Essential role for STAT5 signaling in $\mathrm{CD} 25^{+} \mathrm{CD} 4{ }^{+}$regulatory T cell homeostasis and the maintenance of self-tolerance," Journal of Immunology, vol. 171, no. 7, pp. 3435-3441, 2003.

[24] J. Zhu, J. Cote-Sierra, L. Guo, and W. E. Paul, "Stat5 activation plays a critical role in Th2 differentiation," Immunity, vol. 19, no. 5, pp. 739-748, 2003.

[25] J. Kelly, R. Spolski, K. Imada, J. Bollenbacher, S. Lee, and W. J. Leonard, "A role for Stat5 in CD8 ${ }^{+} \mathrm{T}$ cell homeostasis," Journal of Immunology, vol. 170, no. 1, pp. 210-217, 2003.

[26] J. W. Snow, N. Abraham, M. C. Ma, B. G. Herndier, A. W. Pastuszak, and M. A. Goldsmith, "Loss of tolerance and autoimmunity affecting multiple organs in STAT5A/5Bdeficient mice," Journal of Immunology, vol. 171, no. 10, pp. 5042-5050, 2003.

[27] A. C. Cohen, K. C. Nadeau, W. Tu et al., "Cutting edge: decreased accumulation and regulatory function of $\mathrm{CD} 4^{+} \mathrm{CD} 25^{\text {high }} \mathrm{T}$ cells in human STAT5b deficiency," Journal of Immunology, vol. 177, no. 5, pp. 2770-2774, 2006.

[28] Y. Belkaid, C. A. Piccirillo, S. Mendez, E. M. Shevach, and D. L. Sacks, "CD4 ${ }^{+} \mathrm{CD} 25^{+}$regulatory $\mathrm{T}$ cells control Leishmania major persistence and immunity," Nature, vol. 420, no. 6915, pp. 502-507, 2002.

[29] M. Iwashiro, R. J. Messer, K. E. Peterson, I. M. Stromnes, T. Sugie, and K. J. Hasenkrug, "Immunosuppression by CD4 regulatory $\mathrm{T}$ cells induced by chronic retroviral infection," Proceedings of the National Academy of Sciences of the United States of America, vol. 98, no. 16, pp. 9226-9230, 2001.

[30] B. Singh, S. Read, C. Asseman et al., "Control of intestinal inflammation by regulatory T cells," Immunological Reviews, vol. 182, pp. 190-200, 2001.

[31] S. Sakaguchi, K. Fukuma, K. Kuribayashi, and T. Masuda, "Organ-specific autoimmune diseases induced in mice by elimination of $\mathrm{T}$ cell subset. I. Evidence for the active participiation of $\mathrm{T}$ cells in natural self-tolerance; deficit of a $\mathrm{T}$ cell subset as a possible cause of autoimmune disease," Journal of Experimental Medicine, vol. 161, no. 1, pp. 72-87, 1985.

[32] R. S. McHugh and E. M. Shevach, "Cutting edge: depletion of $\mathrm{CD} 4{ }^{+} \mathrm{CD} 25^{+}$regulatory T cells is necessary, but not sufficient, for induction of organ-specific autoimmune disease," Journal of Immunology, vol. 168, no. 12, pp. 5979-5983, 2002.

[33] T. M. Brusko, C. H. Wasserfall, M. J. Clare-Salzler, D. A. Schatz, and M. A. Atkinson, "Functional defects and the influence of age on the frequency of $\mathrm{CD} 4^{+} \mathrm{CD} 25^{+} \mathrm{T}$-cells in type 1 diabetes," Diabetes, vol. 54, no. 5, pp. 1407-1414, 2005.
[34] S. M. Pop, C. P. Wong, D. A. Culton, S. H. Clarke, and R. Tisch, "Single cell analysis shows decreasing FoxP3 and TGF $\beta 1$ coexpressing $\mathrm{CD} 4^{+} \mathrm{CD} 25^{+}$regulatory $\mathrm{T}$ cells during autoimmune diabetes," Journal of Experimental Medicine, vol. 201, no. 8, pp. 1333-1346, 2005.

[35] Z. Chen, A. E. Herman, M. Matos, D. Mathis, and C. Benoist, "Where $\mathrm{CD} 4{ }^{+} \mathrm{CD} 25^{+} \mathrm{T}$ reg cells impinge on autoimmune diabetes," Journal of Experimental Medicine, vol. 202, no. 10, pp. 1387-1397, 2005.

[36] B. Salomon, D. J. Lenschow, L. Rhee et al., "B7/CD28 costimulation is essential for the homeostasis of the $\mathrm{CD} 4{ }^{+} \mathrm{CD} 25^{+}$ immunoregulatory T cells that control autoimmune diabetes," Immunity, vol. 12, no. 4, pp. 431-440, 2000.

[37] S. Sakaguchi, T. Yamaguchi, T. Nomura, and M. Ono, "Regulatory T cells and immune tolerance," Cell, vol. 133, no. 5, pp. 775-787, 2008.

[38] R. Khattri, T. Cox, S. A. Yasayko, and F. Ramsdell, "An essential role for Scurfin in $\mathrm{CD} 4{ }^{+} \mathrm{CD} 25^{+} \mathrm{T}$ regulatory cells," Nature Immunology, vol. 4, no. 4, pp. 337-342, 2003.

[39] J. Shimizu, S. Yamazaki, T. Takahashi, Y. Ishida, and S. Sakaguchi, "Stimulation of $\mathrm{CD} 25^{+} \mathrm{CD} 4^{+}$regulatory $\mathrm{T}$ cells through GITR breaks immunological self-tolerance," Nature Immunology, vol. 3, no. 2, pp. 135-142, 2002.

[40] C. E. Ruby, M. A. Yates, D. Hirschhorn-Cymerman et al., "Cutting edge: OX40 agonists can drive regulatory T cell expansion if the cytokine milieu is right," Journal of Immunology, vol. 183, no. 8, pp. 4853-4857, 2009.

[41] I. Takeda, S. Ine, N. Killeen et al., "Distinct roles for the OX40OX40 ligand interaction in regulatory and nonregulatory $\mathrm{T}$ cells," Journal of Immunology, vol. 172, no. 6, pp. 3580-3589, 2004.

[42] T. Takahashi, Y. Kuniyasu, M. Toda et al., "Immunologic self-tolerance maintained by $\mathrm{CD} 25^{+} \mathrm{CD} 4^{+}$naturally anergic and suppressive $\mathrm{T}$ cells: induction of autoimmune disease by breaking their anergic/suppressive state," International Immunology, vol. 10, no. 12, pp. 1969-1980, 1998.

[43] R. S. McHugh, M. J. Whitters, C. A. Piccirillo et al., "CD $4{ }^{+} \mathrm{CD} 25^{+}$Immunoregulatory T Cells: gene expression analysis reveals a functional role for the glucocorticoidinduced TNF receptor," Immunity, vol. 16, no. 2, pp. 311-323, 2002.

[44] M. E. Brunkow, E. W. Jeffery, K. A. Hjerrild et al., "Disruption of a new forkhead/winged-helix protein, scurfin, results in the fatal lymphoproliferative disorder of the scurfy mouse," Nature Genetics, vol. 27, no. 1, pp. 68-73, 2001.

[45] S. Piconese, P. Pittoni, A. Burocchi et al., "A non-redundant role for OX40 in the competitive fitness of Treg in response to IL-2," European Journal of Immunology, vol. 40, no. 10, pp. 2902-2913, 2010.

[46] S. Gaudreau, C. Guindi, M. Ménard, G. Besin, G. Dupuis, and A. Amrani, "Granulocyte-macrophage colony-stimulating factor prevents diabetes development in NOD mice by inducing tolerogenic dendritic cells that sustain the suppressive function of $\mathrm{CD}^{+} \mathrm{CD} 25^{+}$regulatory T cells," Journal of Immunology, vol. 179, no. 6, pp. 3638-3647, 2007.

[47] J. D. Fontenot, M. A. Gavin, and A. Y. Rudensky, "Foxp3 programs the development and function of $\mathrm{CD} 4^{+} \mathrm{CD} 25^{+}$ regulatory T cells," Nature Immunology, vol. 4, no. 4, pp. 330$336,2003$.

[48] M. J. Lenardo, "Interleukin-2 programs mouse $\alpha \beta$ T lymphocytes for apoptosis,” Nature, vol. 353, no. 6347, pp. 858-861, 1991.

[49] D. C. Thomis, C. B. Gurniak, E. Tivol, A. H. Sharpe, and L. J. Berg, "Defects in B lymphocyte maturation and Tymphocyte 
activation in mice lacking Jak3," Science, vol. 270, no. 5237, pp. 794-797, 1995.

[50] M. A. Burchill, C. A. Goetz, M. Prlic et al., "Distinct effects of STAT5 activation on $\mathrm{CD} 4^{+}$and $\mathrm{CD} 8^{+} \mathrm{T}$ Cell homeostasis: development of $\mathrm{CD}^{+} \mathrm{CD} 25^{+}$regulatory $\mathrm{T}$ cells versus $\mathrm{CD} 8^{+}$ memory T cells," Journal of Immunology, vol. 171, no. 11, pp. 5853-5864, 2003.

[51] S. J. Bensinger, P. T. Walsh, J. Zhang et al., "Distinct IL-2 receptor signaling pattern in $\mathrm{CD} 4^{+} \mathrm{CD} 25^{+}$regulatory T cells," Journal of Immunology, vol. 172, no. 9, pp. 5287-5296, 2004.

[52] A. M. Thornton, C. A. Piccirillo, and E. M. Shevach, "Activation requirements for the induction of $\mathrm{CD} 4{ }^{+} \mathrm{CD} 25^{+}$ T cell suppressor function," European Journal of Immunology, vol. 34, no. 2, pp. 366-376, 2004.

[53] T. Nishibori, Y. Tanabe, L. Su, and M. David, "Impaired development of $\mathrm{CD} 4^{+} \mathrm{CD} 25^{+}$regulatory $\mathrm{T}$ cells in the absence of STAT1: increased susceptibility to autoimmune disease," Journal of Experimental Medicine, vol. 199, no. 1, pp. 25-34, 2004.

[54] K. A. Smith, "Interleukin-2," Current Opinion in Immunology, vol. 4, no. 3, pp. 271-276, 1992.

[55] M. Papiernik, M. L. de Moraes, C. Pontoux, F. Vasseur, and C. Pénit, "Regulatory CD4 ${ }^{+} \mathrm{T}$ cells: expression of IL-2R $\alpha$ chain, resistance to clonal deletion and IL-2 dependency," International Immunology, vol. 10, no. 4, pp. 371-378, 1998.

[56] T. R. Malek, A. Yu, L. Zhu, T. Matsutani, D. Adeegbe, and A. L. Bayer, "IL-2 family of cytokines in T regulatory cell development and homeostasis," Journal of Clinical Immunology, vol. 28, no. 6, pp. 635-639, 2008.

[57] A. Schimpl, I. Berberich, B. Kneitz et al., "IL-2 and autoimmune disease," Cytokine and Growth Factor Reviews, vol. 13, no. 4-5, pp. 369-378, 2002.

[58] G. Klebb, I. B. Autenrieth, H. Haber et al., "Interleukin2 is indispensable for development of immunological selftolerance," Clinical Immunology and Immunopathology, vol. 81, no. 3, pp. 282-286, 1996.

[59] S. Krämer, C. Mamalaki, I. Horak, A. Schimpl, D. Kioussis, and T. Hünig, "Thymic selection and peptide-induced activation of T cell receptor-transgenic CD8 T cells in interleukin-2deficient mice," European Journal of Immunology, vol. 24, no. 10, pp. 2317-2322, 1994.

[60] T. R. Malek, B. O. Porter, E. K. Codias, P. Scibelli, and A. Yu, "Normal lymphoid homeostasis and lack of lethal autoimmunity in mice containing mature T cells with severely impaired IL-2 receptors," Journal of Immunology, vol. 164, no. 6, pp. 2905-2914, 2000.

[61] T. R. Malek, A. Yu, V. Vincek, P. Scibelli, and L. Kong, "CD4 regulatory $\mathrm{T}$ cells prevent lethal autoimmunity in IL-2R $\beta$ deficient mice: implications for the nonredundant function of IL-2," Immunity, vol. 17, no. 2, pp. 167-178, 2002.

[62] A. R. M. Almeida, N. Legrand, M. Papiernik, and A. A. Freitas, "Homeostasis of peripheral CD4 ${ }^{+}$T cells: IL-2R $\alpha$ and IL-2 shape a population of regulatory cells that controls $\mathrm{CD} 4^{+} \mathrm{T}$ cell numbers," Journal of Immunology, vol. 169, no. 9, pp. 48504860, 2002.

[63] M. A. Gavin, S. R. Clarke, E. Negrou, A. Gallegos, and A. Rudensky, "Homeostasis and anergy of $\mathrm{CD} 4{ }^{+} \mathrm{CD} 25^{+}$suppressor T cells in vivo," Nature Immunology, vol. 3, no. 1, pp. 3341, 2002.

[64] J. F. Bach, "Regulatory T cells under scrutiny," Nature Reviews Immunology, vol. 3, no. 3, pp. 189-198, 2003.

[65] M. de la Rosa, S. Rutz, H. Dorninger, and A. Scheffold, "Interleukin-2 is essential for $\mathrm{CD} 4{ }^{+} \mathrm{CD} 25^{+}$regulatory $\mathrm{T}$ cell function," European Journal of Immunology, vol. 34, no. 9, pp. 2480-2488, 2004.

[66] A. Vella, J. D. Cooper, C. E. Lowe et al., "Localization of a type 1 diabetes locus in the IL2RA/CD25 region by use of tag single-nucleotide polymorphisms," American Journal of Human Genetics, vol. 76, no. 5, pp. 773-779, 2005.

[67] Q. Tang, J. Y. Adams, C. Penaranda et al., "Central role of defective interleukin-2 production in the triggering of islet autoimmune destruction," Immunity, vol. 28, no. 5, pp. 687$697,2008$.

[68] A. Rabinovitch, W. L. Suarez-Pinzon, A. M. James Shapiro, R. V. Rajotte, and R. Power, "Combination therapy with sirolimus and interleukin-2 prevents spontaneous and recurrent autoimmune diabetes in NOD mice," Diabetes, vol. 51, no. 3, pp. 638-645, 2002.

[69] D. V. Serreze, K. Hamaguchi, and E. H. Leiter, "Immunostimulation circumvents diabetes in NOD Lt mice," Journal of Autoimmunity, vol. 2, no. 6, pp. 759-776, 1989.

[70] T. Brusko, C. Wasserfall, K. McGrail et al., "No alterations in the frequency of FOXP3 regulatory T-cells in type 1 diabetes," Diabetes, vol. 56, no. 3, pp. 604-612, 2007.

[71] J. Grant, K. Bourcier, S. Wallace et al., "Validated protocol for FoxP3 reveals increased expression in type 1 diabetes patients," Cytometry Part B, vol. 76, no. 2, pp. 69-78, 2009.

[72] S. Lindley, C. M. Dayan, A. Bishop, B. O. Roep, M. Peatman, and T. I. M. Tree, "Defective suppressor function in $\mathrm{CD} 4{ }^{+} \mathrm{CD} 25^{+}$T-cells from patients with type 1 diabetes," Diabetes, vol. 54, no. 1, pp. 92-99, 2005.

[73] M. Link, L. Salur, K. Kisand, T. Rajasalu, V. Tillmann, and R. Uibo, "Higher FoxP3 mRNA expression in peripheral blood mononuclear cells of GAD65 or IA-2 autoantibody-positive compared with autoantibody-negative persons," APMIS, vol. 116, no. 10, pp. 896-902, 2008.

[74] W. Łuczyński, A. Stasiak-Barmuta, R. Urban, M. Urban, B. Florys, and M. Hryszko, "Lower percentages of T regulatory cells in children with type 1 diabetes-preliminary report," Pediatric Endocrinology, Diabetes, and Metabolism, vol. 15, no. 1, pp. 34-38, 2009.

[75] V. Öling, J. Marttila, M. Knip, O. Simell, and J. Ilonen, "Circulating $\mathrm{CD} 4{ }^{+} \mathrm{CD} 25$ regulatory $\mathrm{T}$ cells and natural killer $\mathrm{T}$ cells in children with newly diagnosed type 1 diabetes or with diabetes-associated autoantibodies," Annals of the New York Academy of Sciences, vol. 1107, pp. 363-372, 2007.

[76] A. L. Putnam, F. Vendrame, F. Dotta, and P. A. Gottlieb, "CD4 ${ }^{+} \mathrm{CD} 25^{+}$regulatory $\mathrm{T}$ cells in human autoimmune diabetes," Journal of Autoimmunity, vol. 24, no. 1, pp. 55-62, 2005.

[77] T. I. M. Tree, B. O. Roep, and M. Peakman, "A mini metaanalysis of studies on $\mathrm{CD} 44^{+} \mathrm{CD} 25^{+} \mathrm{T}$ cells in human type 1 diabetes: report of the immunology of Diabetes Society T cell workshop," Annals of the New York Academy of Sciences, vol. 1079, pp. 9-18, 2006.

[78] Z. Vrabelova, Z. Hrotekova, Z. Hladikova, K. Bohmova, K. Stechova, and J. Michalek, "CD $127^{-}$and FoxP3 ${ }^{+}$expression on $\mathrm{CD} 25^{+} \mathrm{CD} 4^{+} \mathrm{T}$ regulatory cells upon specific diabetogeneic stimulation in high-risk relatives of type 1 diabetes mellitus patients," Scandinavian Journal of Immunology, vol. 67, no. 4, pp. 404-410, 2008.

[79] Z. Yang, Z. Zhou, G. Huang et al., "The CD4 ${ }^{+}$regulatory Tcells is decreased in adults with latent autoimmune diabetes," Diabetes Research and Clinical Practice, vol. 76, no. 1, pp. 126$131,2007$.

[80] Y. Jin, X. Chen, R. Podolsky et al., "APC dysfunction is correlated with defective suppression of $\mathrm{T}$ cell proliferation in 
human type 1 diabetes," Clinical Immunology, vol. 130, no. 3, pp. 272-279, 2009.

[81] J. M. Lawson, J. Tremble, C. Dayan et al., "Increased resistance to $\mathrm{CD} 4{ }^{+} \mathrm{CD} 25^{h i}$ regulatory $\mathrm{T}$ cell-mediated suppression in patients with type 1 diabetes," Clinical and Experimental Immunology, vol. 154, no. 3, pp. 353-359, 2008.

[82] S. A. Long, K. Cerosaletti, P. L. Bollyky et al., "Defects in IL$2 \mathrm{R}$ signaling contribute to diminished maintenance of FOXP3 expression in $\mathrm{CD} 4{ }^{+} \mathrm{CD} 25^{+}$regulatory T-cells of type 1 diabetic subjects," Diabetes, vol. 59, no. 2, pp. 407-415, 2010.

[83] S. A. Long, M. R. Walker, M. Rieck et al., "Functional isletspecific Treg can be generated from $\mathrm{CD} 4^{+} \mathrm{CD} 25^{-} \mathrm{T}$ cells of healthy and type 1 diabetic subjects," European Journal of Immunology, vol. 39, no. 2, pp. 612-620, 2009.

[84] A. L. Putnam, T. M. Brusko, M. R. Lee et al., "Expansion of human regulatory T-cells from patients with type 1 diabetes," Diabetes, vol. 58, no. 3, pp. 652-662, 2009.

[85] A. Ryden, K. Stechova, M. Durilova, and M. Faresjö, "Switch from a dominant Th1-associated immune profile during the pre-diabetic phase in favour of a temporary increase of a Th3associated and inflammatory immune profile at the onset of type 1 diabetes," Diabetes/Metabolism Research and Reviews, vol. 25, no. 4, pp. 335-343, 2009.

[86] A. Schneider, M. Rieck, S. Sanda, C. Pihoker, C. Greenbaum, and J. H. Buckner, "The effector T cells of diabetic subjects are resistant to regulation via $\mathrm{CD}^{+} \mathrm{FOXP}^{+}$regulatory $\mathrm{T}$ cells," Journal of Immunology, vol. 181, no. 10, pp. 7350-7355, 2008.

[87] M. Battaglia, A. Stabilini, B. Migliavacca, J. Horejs-Hoeck, T. Kaupper, and M. G. Roncarolo, "Rapamycin promotes expansion of functional $\mathrm{CD} 4{ }^{+} \mathrm{CD} 25^{+} \mathrm{FOXP}^{+}$regulatory $\mathrm{T}$ cells of both healthy subjects and type 1 diabetic patients," Journal of Immunology, vol. 177, no. 12, pp. 8338-8347, 2006.

[88] P. Monti, M. Scirpoli, P. Maffi et al., "Rapamycin monotherapy in patients with type 1 diabetes modifies $\mathrm{CD} 4^{+} \mathrm{CD} 25^{+} \mathrm{FOXP} 3^{+}$ Regulatory T-Cells," Diabetes, vol. 57, no. 9, pp. 2341-2347, 2008.

[89] D. B. Wilde, M. B. Prystowsky, J. M. Ely, S. N. Vogel, D. P. Dialynas, and F. W. Fitch, "Antigen-reactive cloned helper T cells. II. Exposure of murine cloned helper T cells to IL 2-containing supernatant induces unresponsiveness to antigenic restimulation and inhibits lymphokine production after antigenic stimulation," Journal of Immunology, vol. 133, no. 2, pp. 636-641, 1984.

[90] G. Otten, D. B. Wilde, M. B. Prystowsky et al., "Cloned helper T lymphocytes exposed to interleukin 2 become unresponsive to antigen and concanavalin A but not to calcium ionophore and phorbol ester," European Journal of Immunology, vol. 16, no. 3, pp. 217-225, 1986.

[91] M. S. Jordan, A. Boesteanu, A. J. Reed et al., "Thymic selection of $\mathrm{CD}^{+} \mathrm{CD}^{2} 5^{+}$regulatory $\mathrm{T}$ cells induced by an agonist selfpeptide," Nature Immunology, vol. 2, no. 4, pp. 301-306, 2001.

[92] H. M. van Santen, C. Benoist, and D. Mathis, "Number of $\mathrm{T}$ reg cells that differentiate does not increase upon encounter of agonist ligand on thymic epithelial cells," Journal of Experimental Medicine, vol. 200, no. 10, pp. 1221-1230, 2004. 


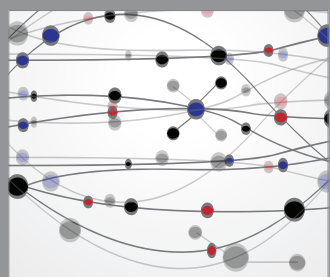

The Scientific World Journal
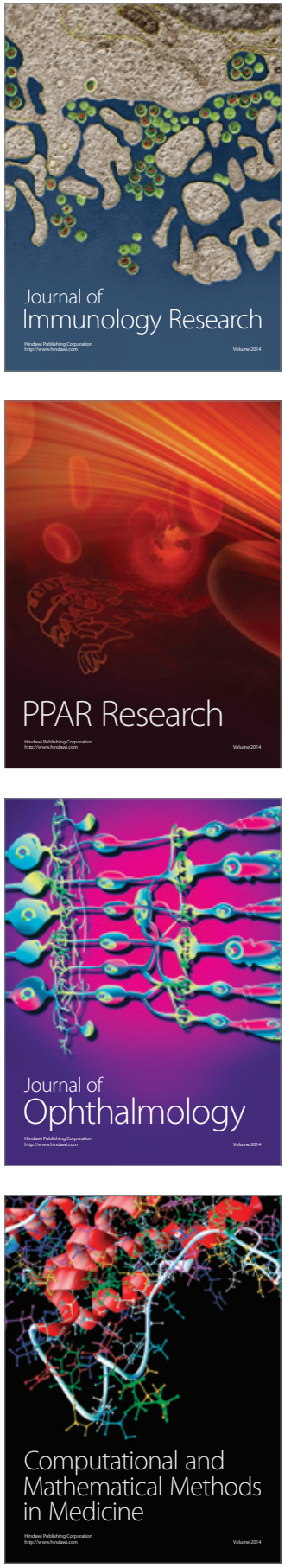

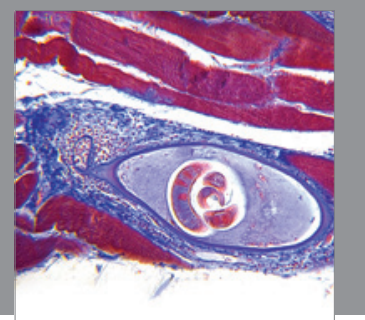

Gastroenterology

Research and Practice
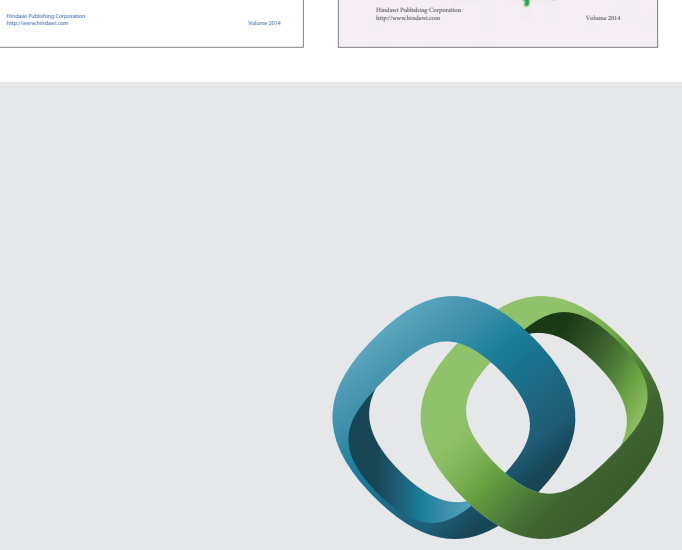

\section{Hindawi}

Submit your manuscripts at

http://www.hindawi.com
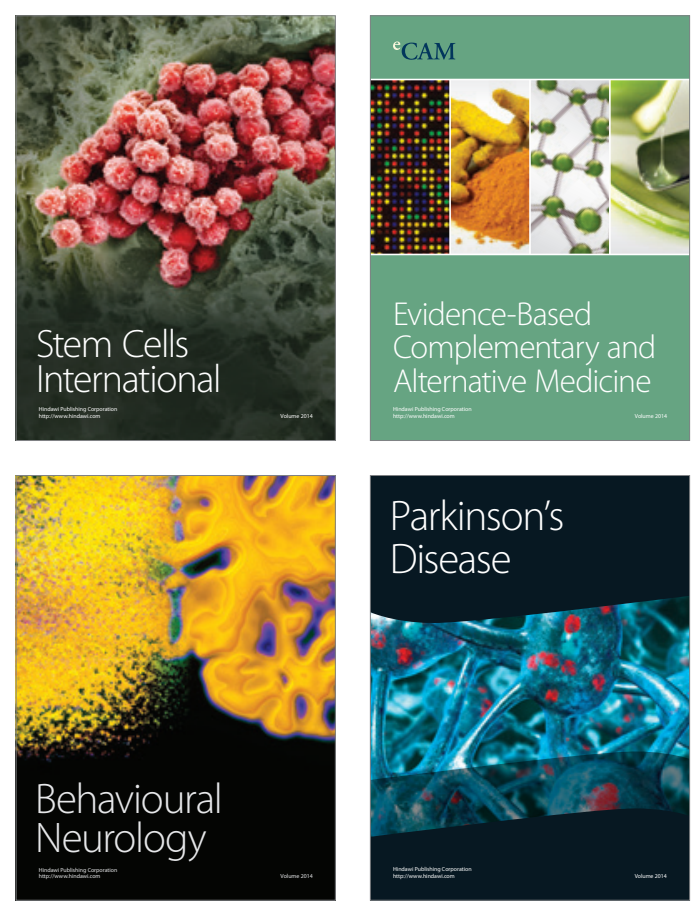

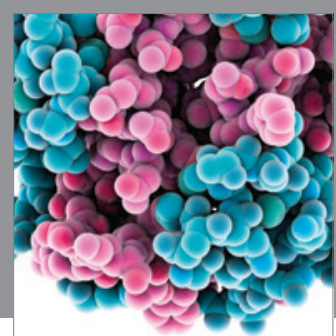

Journal of
Diabetes Research

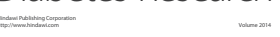

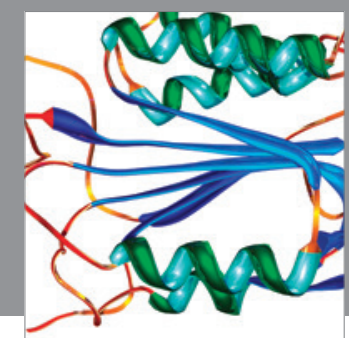

Disease Markers
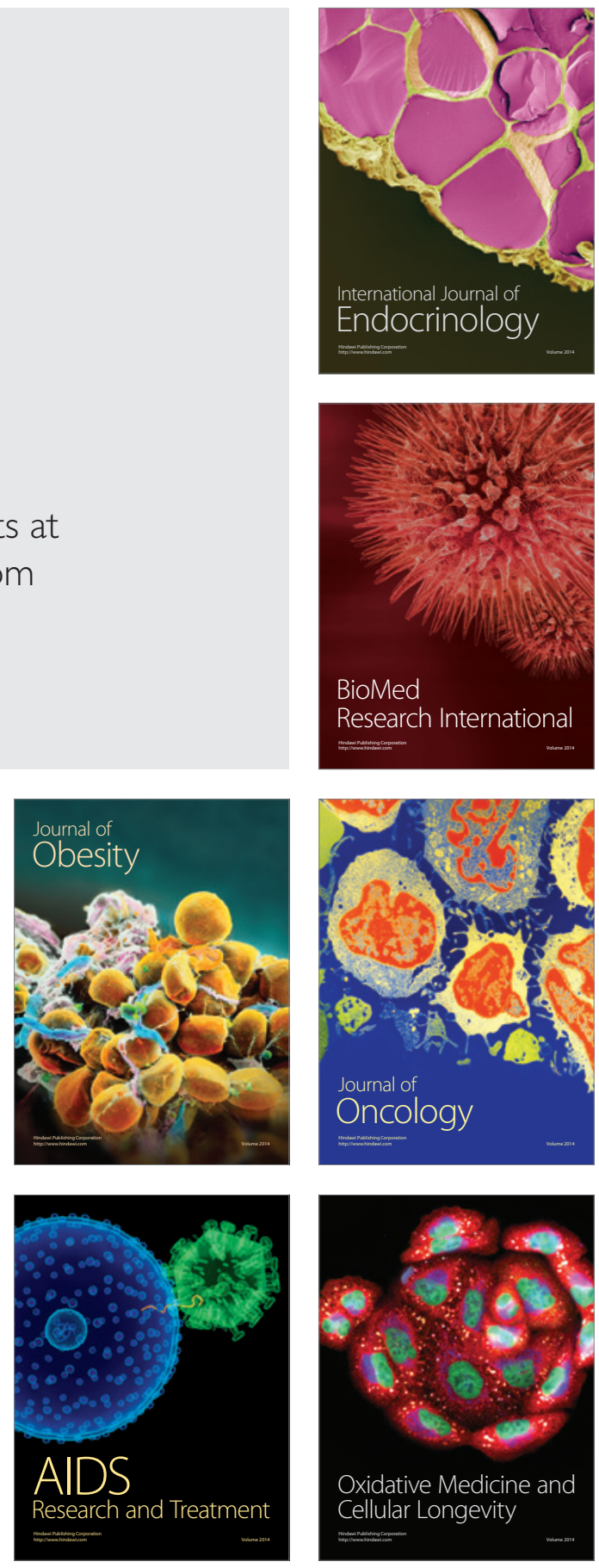